Aưor: Identificação molecular de seqüências

Claudinéla de Araújo

ORIENTADOR: do cromossomo $\mathrm{Y}$ em pacientes com síndrome de Turner

Prof. Dr. ebastião Freitas de Mederos

CO-ORIENTADOR:

Prof. Dr.Marcial Francis Galera

\author{
Molecular identification of $Y$ chromosome sequences in patient \\ with Turner syndrome
}

Resumo de tese

Palavras-chave

Síndrome de Turner Seqüências Y-específicas

Gonadoblastoma

Keywords

Turner syndrome

Y-specific sequences

Gonadoblastoma

AUTORA:

Ana LúCIa Ribeiro Valadares Fernandes

ORIENTADOR:

Prof. Dr. Aarão Mendes Pinto-Neto

CO-ORIENTADOR:

Prof. Dr. Délo Marques Conde

Resumo de tese

Palavras-chave

Sexualidade

Climatério

Meia-idade

Satisfação sexual

Parceiro sexual

Key words

Sexuality

Climacteric

Middle-age

Sexual satisfaction

Sexual partner
Dissertação de Mestrado apresentada ao Programa de Pós-graduação Stricto Sensu em Ciências da Saúde da Universidade Federal de Mato Grosso, em 21 de fevereiro de 2008.

A investigação de seqüências Y-específicas em pacientes com síndrome de Turner (ST), cariótipo 45, X ou mosaico, tem papel fundamental na abordagem terapêutica e seguimento destas pacientes. A relação entre a presença de fragmentos do cromossomo $\mathrm{Y}$ e maior risco de gonadoblastoma na ST está estabelecida. OBJETIVO: investigar a presença de fragmentos do cromossomo Y em pacientes com ST. MÉTODOS: foram incluídas 42 pacientes com ST, idade média de

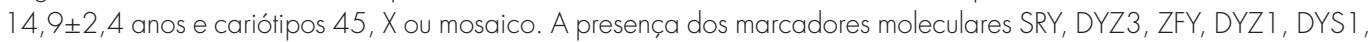
PABY foi investigada pela técnica de reação em cadeia da polimerase (PCR), utilizando DNA genômico dos linfócitos do sangue periférico. O estudo foi aprovado pelo Comitê de Ética do Hospital Geral Universitário. RESULTADOS: nenhuma das pacientes estudadas apresentou qualquer fragmento Y-específico quando suas células foram analisadas apenas pela técnica citogenética clássica. Por meio da investigação por PCR, as seqüências Y-específicas ZFY e DYZ3 foram identificadas em duas pacientes (4,8\%), ambas com cariótipo 45, X. Clinicamente, a paciente com fragmento ZFY apresenta mandíbula pequena, palato em ogiva, dentes sobrepostos, espina bífida, otite, cardiopatia, timidez excessiva e dificuldade no desempenho escolar. A paciente que apresentou a seqüência DYZ3 possui tendência a quelóides, maxilar estreito, dentes sobrepostos, espina bífida, deformidade dos pés, otite, rim em ferradura e grande dificuldade no desempenho escolar. CONCLUSÃO: a PCR é eficiente e necessária na investigação de mosaicismo oculto em pacientes com a síndrome de Turner, uma vez que estas têm um risco maior para o desenvolvimento de gonadoblstoma.

\section{Sexualidade em mulheres entre 40 e 65 anos e com 11 anos ou mais de escolaridade: estudo de base populacional}

\author{
Sexuality in women of 40-65 years old with 11 years or more \\ of formal education: a population-based study
}

Tese apresentada ao Departamento Tocoginecologia da Universidade Estadual de Campinas para obtenção do título de Doutor em Ginecologia e Obstetrícia, em 17 de dezembro de 2007.

OBJETIVOS: avaliar a sexualidade e seus fatores associados em mulheres de meia-idade. MÉTODOS: realizou-se estudo populacional de corte transversal em Belo Horizonte, Minas Gerais, no qual foram incluídas 378 mulheres brasileiras com idade entre 40 e 65 anos e com 11 com anos ou mais de escolaridade. $\bigcirc$ instrumento de avaliação da sexualidade baseou-se no Short Personal Experience Questionnaire. Foram investigados: presença de fantasias sexuais, grau de desejo, freqüência e satisfação na atividade sexual, freqüência de excitação, orgasmo e a auto-classificação da vida sexual. Avaliaram-se dados sociodemográficos, comportamentais, relativos à saúde e ao parceiro. Calculou-se a mediana do escore de sexualidade. Valores acima da mediana foram considerados como indicativos de boa sexualidade, enquanto valores abaixo da mediana indicaram sexualidade ruim. RESULTADOS: a mediana do escore de sexualidade foi 9. Na análise de regressão múltipla, a prevalência de escore abaixo da mediana foi maior nas mulheres com maior idade e naquelas com insônia. Ter parceiro sexual e sentir-se bem associaram-se à boa sexualidade. Entre mulheres com parceiro sexual, residir com o parceiro, ter hipertensão e estar na transição climatérica ou na pós-menopausa associaram-se à sexualidade ruim. Relação sexual com penetração e satisfação com o parceiro como amante indicaram efeito protetor contra sexualidade ruim. CONCLUSÕES: esses dados sugerem que, em mulheres com idade entre 40 e 65 anos, a existência de um parceiro sexual pode contribuir para melhorar a sexualidade. Porém, isto não é suficiente para garantir uma vida sexual satisfatória, uma vez que mesmo mulheres com parceiro sexual podem apresentar uma sexualidade ruim determinada por outros fatores. 